\title{
1. Rule of law and areas of limited statehood: introduction and perspective
}

\author{
Linda Hamid and Jan Wouters
}

\subsection{SETTING THE SCENE}

On 21 March 2020, the leaders of Comando Vermelho, a criminal group in control of Rocinha, one of Rio de Janeiro's most populous favelas, sent a message to residents announcing a stay-at-home order in a bid to curb the spread of the novel coronavirus. 'If the government does not have the capacity to fix it, organized crime will solve it', ${ }^{1}$ they quipped. An increasing number of criminal groups active across Rio soon followed suit. With a mostly absent central government in the greater part of Brazil's favelas, ${ }^{2}$ these gangs instead responded to the COVID-19 pandemic by imposing strict curfews, broadcasting public-hygiene announcements, limiting social gatherings, or distributing soap and other protective equipment. ${ }^{3}$ In short, in lieu of State and federal authorities, criminal groups in Brazil have taken it upon themselves to ensure that favela residents comply with quarantine measures or else 'be punished'. ${ }^{4}$

This example perfectly embodies some of the core subjects that the contributors to this volume have set out to examine. Moreover, since it is of recent date, it also illustrates the timeliness of this book. Given that State authority

\footnotetext{
1 'Coronavírus: tráfico e milícia impõem toque de recolher em favelas do Rio', Veja (Rio de Janeiro, 24 March 2020) https://veja.abril.com.br/brasil/coronavirus -trafico-e-milicia-impoem-toque-de-recolher-em-favelas-do-rio/.

2 Tanja A Börzel, Thomas Risse and Anke Draude, 'Governance in Areas of Limited Statehood: Conceptual Clarifications and Major Contributions of the Handbook' in Thomas Risse, Tanja A Börzel and Anke Draude (eds) The Oxford Handbook of Governance and Limited Statehood (Oxford University Press 2018) 8.

3 See, eg, Caio Baretto Briso and Tom Philips, 'Brazil gangs impose strict curfews to slow coronavirus spread', The Guardian (Rio de Janeiro, 25 March 2020) https:// www.theguardian.com/world/2020/mar/25/brazil-rio-gangs-coronavirus.

4 Ibid.
} 
or control are lacking in Rio's many favelas, shantytowns like Rocinha can be defined as 'areas of limited statehood' (ALS), a term first coined by political scientists at the Collaborative Research Center (SFB) 700 'Governance in Areas of Limited Statehood', 5 and defined by Thomas Risse as 'parts of a country in which central authorities (governments) lack the ability to implement and enforce rules and decisions or in which the legitimate monopoly over the means of violence is lacking, at least temporarily'. ${ }^{6}$ However, as underscored by Tanja Börzel, Risse and Anke Draude, ALS are 'neither ungovernable nor ungoverned' spaces. ${ }^{7}$ Rather, ALS will often be governed by what we call in this volume 'alternative governors'. Indeed, in light of a mostly, if not entirely absent State, the gangs ruling Rio's favelas, although broadly malign actors whose main field of activity is criminal, will often engage in day-to-day governance, providing (non-state) justice and basic public services. ${ }^{8}$ This displacement of functions traditionally associated with the State at the hands of alternative governors raises numerous rule of law (RoL) dilemmas. For instance, the nature and legal basis of the punishment threatening quarantine transgressors in Rocinha are certainly dubious. Would a punishment administered ad-hoc by Comando Vermelho, outside the framework of the central government's laws and institutions, comply with basic RoL principles, such as nulla poena sine lege or the prohibition of arbitrariness? Arguably not. ${ }^{9}$ Moreover, since groups such as these are often involved in transnational organized crime, they may also raise international security concerns, thus challenging the international rule of law (IRoL) as well.

5 For an overview of the Center's research, see the Collaborative Research Center (SFB) 700 'Governance in Areas of Limited Statehood', https://www.sfb-governance .de/en/.

6 Thomas Risse, 'Governance in Areas of Limited Statehood: Introduction and Overview' in Thomas Risse (ed) Governance Without a State? Policies and Politics in Areas of Limited Statehood (Columbia University Press 2013) 4. This definition starts from a narrow understanding of statehood as developed in political discourse by Max Weber, whereby the State is characterized 'as a human community that successfully claims the monopoly of the legitimate use of physical force within a given territory'. See Max Weber, 'Politics as a Vocation' in Hans H Gerth and Charles W Mills (eds and trs) From Max Weber: Essays in Sociology (Oxford University Press 1946) 78.

7 Börzel, Risse and Draude (n 2) 8-9.

8 See, eg, Ryan Berg and Andrea Varsori, 'Covid-19 is increasing the power of Brazil's criminal groups' (LSE Latin America and Caribbean Blog, 28 May 2020) https://blogs.lse.ac.uk/latamcaribbean/2020/05/28/covid-19-is-increasing-the-power -of-brazils-criminal-groups/.

9 On the core elements of the RoL, see generally CoE Venice Commission, 'Report on the Rule of Law' (4 April 2011) CDL-AD(2011)003rev, and in particular 'Annex: Checklist for evaluating the state of the rule of law in single states'. 
Moving beyond this present-day example and its illustrative unpacking, the ALS phenomenon and the manifold challenges it poses to both domestic and international legal orders has been with us for some time now. As Risse explains, ALS are 'an almost ubiquitous phenomenon in the contemporary international system, but also in historical comparison'. ${ }^{10}$ Moreover, ALS are also a geographically widespread phenomenon, affecting both developed and developing countries across the globe. ${ }^{11}$ Using this concept as a common analytical framework, for a little over a decade (from 2006 to 2017), dozens of researchers from multiple disciplinary backgrounds at the SFB 700 examined aspects of governance in ALS, ${ }^{12}$ yielding numerous and impressive outputs in the form of working papers, journal articles and special issues, as well as monographs and edited volumes. ${ }^{13}$ Among these, two contributions (already referenced here) stand out in particular in light of their comprehensiveness: Governance without a State? Policies and Politics in Areas of Limited Statehood, a 2011 volume edited by Risse and integrating mainly political perspectives on the ALS phenomenon, but also legal and historical ones, ${ }^{14}$ and the relatively recent Oxford Handbook of Governance and Limited Statehood, edited by Risse, Börzel and Draude, which provides an extensive overview of the ALS phenomenon and examines its implications for the State system, global governance and the future of global politics from a multidisciplinary perspective, including political science, social anthropology, history, geography, economics and law. ${ }^{15}$ With respect to the latter, only one among a total of 29 chapters gives an international law perspective on the topic. In her chapter on 'International Legal Order', Heike Krieger offers an interesting and much needed legal account of how international law - and a principally State-oriented international legal system - has dealt with the phenomenon of ALS over the past decades. ${ }^{16}$ Krieger was also one of the forces behind International Humanitarian Law and Areas of Limited Statehood: Adaptable and Legitimate or Rigid and Unreasonable?, a volume edited by Björnstjern Baade, Linus Mührel and Anton Petrov and examining the impact of ALS on

\footnotetext{
Risse (n 6) 6.

Ibid 5-7.

SFB 700 'Governance in Areas of Limited Statehood' (n 5).

Ibid.

Thomas Risse (ed) Governance Without a State? Policies and Politics in Areas of Limited Statehood (Columbia University Press 2013). The edited volume includes 10 contributions that examine, among others, the role of non-state actors in the governance of ALS and the contribution of external actors to State-building and good governance in countries with limited statehood.

15 Thomas Risse, Tanja A Börzel and Anke Draude (eds) The Oxford Handbook of Governance and Limited Statehood (Oxford University Press 2018).

${ }_{16}$ Heike Krieger, 'International Legal Order' in Risse, Börzel and Draude (n 15).
} 
international humanitarian law. ${ }^{17}$ Apart from these titles, the notion of ALS is rarely encountered in international legal scholarship. ${ }^{18}$ This volume, however, intends to partly alleviate this scarcity.

In 2016, together with Amichai Magen from the Lauder School of Government, Diplomacy and Strategy from the IDC Herzliya in Israel, we assembled a group of scholars - predominantly from the legal discipline, but also political science - to reflect on the RoL challenges posed by ALS in terms of not only domestic RoL conditions but also, and in particular, international law and the IRoL. Two focused workshops were thus organized: the first was held in Israel, at the Lauder Schools of Government, Diplomacy and Strategy, IDC Herzliya on 27-28 June 2016, ${ }^{19}$ with discussions being continued on 29-30 September in Belgium, at the Leuven Centre for Global Governance Studies, KU Leuven. During these two workshops, participants presented and exchanged views on a wide variety of issues ranging from RoL and IRoL dilemmas arising from competing sovereignty claims in ALS, to the consequences on the international plane of governance provision by criminal or violent non-state actors (NSAs) operating in ALS, atrocity prevention, counter-terrorism, peacekeeping and the promotion of the RoL and human rights in ALS by international actors such as the United Nations (UN). The insights acquired in the course of these two encounters are reflected in the contributions to this volume.

\subsection{CENTRAL CONCEPTS OF THE VOLUME: SOME CLARIFICATIONS IN CONTEXT}

\subsubsection{Areas of Limited Statehood}

As observed by Risse, the political discourse on governance remains centred on the ideal, modern model of statehood, 'with full internal and external sovereignty, a legitimate monopoly on the use of force, and checks and balances that constrain political rule and authority'. ${ }^{20}$ The political discourse on global governance, he further emphasizes, 'is [also] based on the assumption that

17 Björnstjern Baade, Linus Mührel and Anton O Petrov, International Humanitarian Law in Areas of Limited Statehood: Adaptable and Legitimate or Rigid and Unreasonable? (Nomos 2018).

18 For another rare occurrence, see Beate Rudolf, 'Non-State Actors in Areas of Limited Statehood as Addressees of Public International Law Norms on Governance' (2010) 4(1) Human Rights and International Legal Discourse 127.

19 This first workshop was kindly sponsored by the Israel Office of the Konraud Adenauner Stiftung.

20 Risse (n 6) 1. 
functioning states are capable of implementing and enforcing global norms and rules'. ${ }^{21}$ Likewise, in his influential work on States in international law, James Crawford encapsulates the notion of statehood in a similar manner and using the simplest of expressions: 'statehood as effectiveness'. ${ }^{22}$ Indeed, most approaches to modern international law are based on an underlying assumption that its main actors are 'fully sovereign' States that exercise effective and exclusive governmental authority in both their international and external affairs. ${ }^{23}$ As principal participants in the international legal system, States are normally expected to be able and willing to fulfil their international obligations. Take, for instance, the UN Charter, stipulating that membership to the UN 'is open to all other peace-loving states which accept the obligations contained in the present Charter and, in the judgment of the Organization, are able and willing to carry out these obligations'. ${ }^{24}$ Because of this 'binary and categorical approach', Krieger argues, ${ }^{25}$ the international legal discourse has mainly focused on 'failing' or 'failed' States, ${ }^{26}$ notions that should however be distinguished from ALS since the latter's benchmark is not the ideal, highly functional model of statehood. Instead, the mainly political ALS discourse accepts that 'empirical variations of effective government' 27 are ubiquitous and that, therefore, statehood may also be partly limited along various dimensions, and not necessarily fully collapsed. However, (international) law will rarely accept the empirical reality of statehood as a variable. ${ }^{28}$ This reluctance, as shall be seen throughout this volume, leads to RoL tensions at both the national and the international levels.

This book will not depart from the definitions of the ALS concept as adopted in the context of the research undertaken by the SFB 700. Rather, the volume embraces the limited statehood framework as its background, adding a new, mostly international law-centred perspective on the subject matter. As discussed, ALS are those parts of a State where the government has lost its capacity to implement and enforce central rules and decisions, and/or in which

\section{Ibid 1-2.}

22 See, eg, James Crawford, The Creation of States in International Law (Oxford University Press 2007) and, more specifically, the second chapter on 'The Criteria for Statehood: Statehood as Effectiveness' 37-95.

23 Börzel, Risse and Draude (n 2) 8.

24 Charter of the United Nations (adopted 24 October 1945, entered into force 31 August 1965) 1 UNTS XVI, art 4.

$25 \quad$ Krieger (n 16) 545.

26 See, eg, Daniel Thürer, 'The "Failed State" and International Law' (1999) 81(836) International Review of the Red Cross 731.

27 Krieger (n 16) 545.

28 Ibid. 
it no longer commands a monopoly over the means of violence. ${ }^{29}$ States marred by ALS retain their international legal sovereignty, ${ }^{30}$ in that they remain recognized by other States and their independence and territorial integrity is upheld, at least in principle, by the international community. Instead, it is their domestic sovereignty, namely 'the ability of public authorities to exercise effective control within [their] own borders' ${ }^{31}$ that is harshly circumscribed in practice. Moreover, their Westphalian sovereignty, construed by Stephen Krasner as 'the exclusion of external actors, whether de facto or de jure' 'from authority structures within a given territory', ${ }^{32}$ and interdependence sovereignty, which is concerned 'with the capacity of a state to regulate movement across its borders', ${ }^{33}$ will probably also incur severe limitations in the presence of an ALS. Therefore, as Risse further observes, various models of limited statehood can be imagined. Indeed, apart from the territorial model, in which the capacity of the central authorities is affected only in certain parts of a country, statehood may also be limited across sectors and in certain policy areas only; socially, that is in relation to specific categories of a State's population; or temporally, namely for a short-lived period. ${ }^{34}$

These conditions will severely impair the State's ability to provide effective and legitimate governance in ALS. While the notion of 'governance' is not specific to the legal literature, we adopt in this volume the same understanding as that employed in the context of the ALS paradigm, namely 'the various institutional modes of social coordination to produce and implement collectively binding rules, or to provide collective goods'. ${ }^{35}$ As such, the notion of 'effectiveness' will then imply that 'binding rules and collective goods are actually delivered' in $\mathrm{ALS},{ }^{36}$ whereas 'legitimacy' essentially refers to a licence or right to govern, which can be either empirical or normative. ${ }^{37}$ In light of these considerations, we can think of ALS as defined by sovereignty or governance gaps such as (but by no means limited to): security gaps caused by the State's inability to ensure a monopoly over the use of force; capacity gaps

\footnotetext{
$29 \quad$ Risse (n 6).

30 Stephen D Krasner, Sovereignty: Organized Hypocrisy (Princeton University Press 1999) 3.

31 Ibid 4.

32 Ibid.

33 Ibid.

34 Risse (n 6) 4-5.

35 Ibid 9. See also Zachariah C Mampilly, Rebel Rulers: Insurgent Governance and Civilian Life During War (Cornell University Press 2011) 4, where the author refers to the governance dispensed by rebels along the same lines, namely as the manner in which these rebels regulate life within a defined territory and provide public services.

36 Börzel, Risse and Draude (n 2) 12.

37 Ibid 12-13.
} 
resulting from the State's inability to provide collective goods, including law and order; legitimacy gaps, which emerge when the State no longer commands the loyalty of its population; human wellbeing gaps, implying widespread human rights abuses, economic decline, extreme violence, etc.; and collaborative gaps, which relate to the State's unwillingness or inability to collaborate with other States or international organizations (IOs) to address transnational and international challenges.

Understood as such, ALS then unravel as a truly omnipresent phenomenon that affects not only developing States, but also developed ones. Think, for instance, no farther than the example provided at the outset of this introduction, in which Brazil, a major emerging market, sees its domestic sovereignty stifled in the favelas and in large parts of the Amazon, ${ }^{38}$ or Cyprus, a European Union Member State that has fully lost control over the northern part of its island since the Turkish invasion of 1974 and the 1983 declaration of independence by the so-called Turkish Republic of Northern Cyprus, a de facto regime. ${ }^{39}$ Since these latter events also engaged core international law values, such as the prohibition on the use or threat of force and the principle of territorial integrity, they naturally overflowed onto the international plane as well, raising not only RoL questions, but also IRoL ones. ${ }^{40}$ ALS therefore can be found anywhere, and are certainly not confined to failing or failed States. On the contrary, as the previous examples and the chapters in this volume illustrate, ALS may also be found in otherwise functional States. As an analytical framework, limited statehood goes beyond the consolidated statehood/failing or failed statehood dichotomy, epitomizing an obvious but often overlooked truth: statehood and sovereignty are not a black or white affair. Moreover, as Baade, Mührel and Petrov observe, the ALS concept describes the empirical reality in a more neutral manner, leaving aside normative and so-called Western-biased judgments as to State failure in relation to ideal models of effective statehood. ${ }^{41}$ Finally, as the themes explored in this book will also reflect, the ALS approach goes beyond the legal aspects typically investigated in the context of the discourse on State failure (legal personality, sovereignty and formal State

38 Ibid 8.

39 Jochen A Frowein, 'De Facto Regime' in Rüdiger Wolfrum (ed) The MaxPlanck Encyclopedia of Public International Law (online edn, Oxford University Press, March 2013) para 1. See also Linda Hamid and Jan Wouters, 'De Facto Regimes in Areas of Limited Statehood and the International Rule of Law', Chapter 3 in this volume.

40 UN Security Council Resolution 541 (18 November 1983) UN Doc S/RES/541. See also Cyprus v Turkey App no 25781/94 (ECtHR, 10 May 2001).

${ }^{41}$ Heike Krieger, Björnstjern Baade and Linus Mührel, 'Introduction: International Humanitarian Law and Areas of Limited Statehood' in Baade, Mührel and Petrov (eds) (n 17) 23. 
equality, prohibition of the use of force and the principle of non-intervention, etc.). ${ }^{42}$ Indeed, since the limited statehood paradigm acknowledges that governance is no longer the sole attribute of States, whether by choice or by force, it largely focuses on the actors, State and non-state alike, that will step in to fill the various governance gaps. As such, the ALS framework opens the door to new research questions relating, in principle, to the effectiveness or legitimacy of the governance dispensed by alternative governors and the consequences thereof for a State-centred international legal system. ${ }^{43}$

\subsubsection{Alternative Governors in Areas of Limited Statehood}

The concept of ALS does not necessarily imply that a certain space, policy sector or social category is completely devoid or deprived of governance. As already highlighted, ALS are usually not ungoverned, per se. Rather, governance is supplied by alternative governors, and not the de jure government of a State. In this volume, we use the expression 'alternative governors' as an umbrella term that encompasses the variety of actors that may step in, either with the approval of the central authorities, to compensate for the limitedness of statehood and perform government-like functions in lieu of the State, or forcibly, to contest and/or usurp the authority of the territorial State. Therefore, alternative governors may be broadly benign, stability-providing actors, such as the UN's administration of territory in Kosovo or East Timor ${ }^{44}$ or its multiple peacekeeping operations deployed around the world, or malign, such as rebel groups and warlords, or even terrorist groups. ${ }^{45} \mathrm{At}$ the same time, as these examples and the ensuing contributions to this volume reflect, alternative governors may be either external actors, usually outside States and IOs, or local actors like de facto regimes or non-state armed groups (NSAGs). At this point, we should also note that the designation used in this volume does not imply homogeneity. Therefore, the terms used in the ensuing chapters, which range from de facto regimes to NSAGs, rebel governors, non-state rulers, or simply external actors, also reflect the diversity of alternative governors.

The presence of alternative governors will severely hamper not only a State's domestic sovereignty, threatening the national RoL, but also its capacity to fulfil its international obligations in line with the IRoL. Take, for instance, the situation of Crimea, extensively examined in Chapter 4 of this volume, or that

\footnotetext{
Krieger (n 16) 545-546; Thürer (n 26).
}

43 For a similar observation, see also Krieger, Baade and Mührel (n 41).

44 On the international administration of territory, see generally Ralph Wilde,

'From Danzig to East Timor and Beyond: The Role of International Territorial Administration' (2001) 95(3) American Journal of International Law 583.

45 Börzel, Risse and Draude (n 2) 10. 
of the de facto regimes established in places such as Abkhazia or Transnistria, depicted in Chapter 3. When statehood is limited because of either occupation by an outside State, or the installation of a separatist regime, the lawful sovereign will be unable to fulfil, among others, its obligations under international human rights law (IHRL), as these are normally bound up with and dependent on the effective functioning of the State. Moreover, contested sovereignty and a lack of empirical and normative legitimacy at both the local and the international levels, as showcased in relation to Israel and East Jerusalem in Chapter 5 of this volume, will not only frustrate the (outside) State's ability to govern, but also raise questions as to its obligations under the international law of occupation. On the other hand, when governance is exercised by actors like NSAGs which, as depicted in Chapter 6 in this volume, may provide so-called 'rebel justice', further concerns as to whether such NSAs can dispense law enforcement and justice functions in line with basic RoL requirements, or the conditions under which they are bound by international legal obligations, will certainly arise. As Chapters 7 and 8 in this book will reflect, when NSAGs (or other non-state rulers) engage in abusive conduct, transgressing the boundaries of international law, questions as to the international responsibility of either the State where they operate or the NSAs themselves inevitably have to be pondered. Lastly, limited statehood and internal strife caused by terrorist groups or rebels and warlords will often result in a State's failure to prevent transnational crime, violent extremism and atrocity crimes, despite incurring the primary obligation to do so under international law. ${ }^{46}$ Since these scenarios also threaten international peace and security, other States as well as IOs will usually respond to them. Chapters 9-11 in this volume each examine various global reactions to the security challenges posed by certain ALS, ranging from the deployment of UN peacekeeping missions to the development of a global counter-terrorism strategy and, respectively, atrocity prevention frameworks associated with the Responsibility to Protect (R2P). More importantly, the chapters test these external reactions and interventions against their potential not only to enhance, but also to undermine the RoL at both the national, transnational and international levels.

\subsubsection{The (International) Rule of Law}

It is important to clarify, at the very outset, that this volume does not employ pre-ordained definitions of the RoL and IRoL. As the literature lays bare, and as it became evident during our two collaborative workshops, neither the RoL

46 See, eg, Convention on the Prevention and Punishment of the Crime of Genocide (adopted 9 December 1948, entered into force 12 January 1951) 78 UNTS 277, art I. 
nor the IRoL have an established, agreed upon definition. As far as the RoL is concerned, at the heart of the struggle for meaning lies a fundamental choice between so-called 'formal', or 'thin' understandings of the RoL and 'substantive' or 'thick' conceptualizations. ${ }^{47}$ On the one hand, formal conceptions tend to stress procedural safeguards and overall legality, such as the accessibility, predictability, publicity and generality of the law. For instance, one of the main contemporary supporters of this conception, Joseph Raz, has posited that the RoL 'means literally what it says: the rule by law', and that 'in its broadest sense this means that people should obey the law and be ruled by it'. ${ }^{48}$ On the other hand, substantive understandings of the RoL include, in addition to procedural guarantees, concerns about the content of laws, which is argued should enshrine and protect human rights also. ${ }^{49}$ Bringing the various scholarly approaches together, but also looking at national and international legal instruments, the European Commission for Democracy through Law (Venice Commission) has concluded that there is, in fact, a core meaning of the RoL and a consensus on its essential elements. This is a thick meaning that consists of legality, including a transparent, accountable and democratic process for enacting laws; legal certainty; the prohibition of arbitrariness; access to justice before independent and impartial courts; respect for human rights; and non-discrimination and equality before the law. ${ }^{50}$

As far as the international dimension of the RoL is concerned, definitional approaches likewise oscillate between two choices along the formalistic and substantive divide. First, there are those who advance a meaning that seeks to directly transpose the domestic RoL at the international level, such as Stéphane Beaulac $^{51}$ or Simon Chesterman. The latter, for instance, argues that the IRoL can be said to refer to 'the application of rule of law principles to relations between States and other subjects of international law'. ${ }^{52}$ These approaches

47 Brian Z Tamanaha, On the Rule of Law (Cambridge University Press 2004) 92.

48 Joseph Raz, 'The Rule of Law and its Virtue' in Joseph Raz, The Authority of Law: Essays on Law and Morality (Clarendon Press 1979) 210.

49 See, eg, Tom Bingham, The Rule of Law (Penguin Books 2010) 66-67. See, in contrast, $\operatorname{Raz}$ (n 48) 211, where the author argues that '[a] non-democratic legal system, based on the denial of human rights, on extensive poverty, on racial segregation, sexual inequalities, and religious persecution may, in principle, conform to the requirements of the rule-of-law better than any of the legal systems of the more enlightened Western democracies'.

50 Venice Commission, 'Report on the Rule of Law' (n 9) para 41 et seq. and 'Annex: Checklist for evaluating the state of the rule of law in single states'.

51 Stéphane Beaulac, 'The Rule of Law in International Law Today' in Gianluigi Palombella and Neil Walker (eds) Relocating the Rule of Law (Hart Publishing 2009).

52 Simon Chesterman, 'An International Rule of Law' (2008) 56(2) American Journal of Comparative Law 331, 355. 
tend to yield formalistic views that often conflate the IRoL with States' obligation to comply with international law. ${ }^{53}$ At the other end of the spectrum, some contend that the core meaning of the RoL ideal, which is the protection of the individual against an arbitrary or unjust use of governing power, ${ }^{54}$ 'is not lost when transposed to the international level'. ${ }^{55}$ This then leads to substantive definitions of the RoL at the international level. For instance, in a relatively recent piece, Robert McCorquodale defines the IRoL by reference to 'the objectives of a rule of law', which largely coincide with the core elements of the domestic RoL as identified by the Venice Commission: 'legal order and stability; equality of application of the law; protection of human rights; and the settlement of disputes before an independent legal body'. ${ }^{56}$

The breadth and diversity of the concept and its understanding are therefore also reflected in the contributions to this volume, which also oscillate between formal and substantive conceptions in their quest to explore how much (I)RoL there can be in and in relation to ALS. For instance, some authors approached their topics from only the perspective of the domestic RoL (e.g. Chapters 5 and 6), some employed the IRoL as the sole analytical lens (e.g. Chapters 3, 7 and 8), whereas others ambitiously focused on both (mainly Chapters 4 and 9). At times, the yardstick for analysis is the formalistic definition of the RoL, which is mostly focused on aspects of legality (e.g. Chapters 5, 9 and 11), whereas at other times the benchmark is a thicker RoL that also includes conditions on the content of the laws (e.g. Chapter 6). As for the IRoL, while some contributions frame it simply as a legal ordering of the international community under the baton of an effectively applied and enforced international law (e.g. Chapter 4), others posit that many elements of the domestic RoL, including some of the thicker ones like the protection of human rights, can and should be transposed at the international level. In this sense, an understanding that other ruling actors, and not just States, should be bound by the IRoL also emerges (e.g. Chapters 3 and 8).

Notwithstanding this variety of approaches, what remains true is that the traditional conceptualization of the RoL, in both its national and its international

53 For a critique, see Robert McCorquodale, 'Defining the International Rule of Law: Defying Gravity?' (2016) 65(2) International and Comparative Law Quarterly 277, 288-291.

54 McCorquodale (n 53) 292.

55 Janne E Nijman, 'Non-State Actors and the International Rule of Law: Revisiting the "Realist Theory" of International Legal Personality' in Math Noortmann and Cedric Ryngaert (eds) Non-State Actor Dynamics in International Law: From Law-Takers to Law-Makers (Routledge 2010) 99.

56 McCorquodale (n 53) 292. See also Arthur Watts, 'The International Rule of Law' (1993) 36 German Yearbook of International Law 15. 
milieus, is very much State-based. Chapter 2 in this volume, for instance, tracks the history of the RoL-State nexus nearly four centuries back. To a large extent, this understanding remains prevalent today. For example, no farther than 2011, the Venice Commission indicated that, viewed in its historical context, the RoL 'addresses the exercise of power and the relationship between the individual and the state'. ${ }^{57}$ Legality, legal certainty, the prohibition of arbitrariness, access to justice before independent and impartial courts, respect for human rights and equality before the law, as the core elements of the (domestic) RoL identified by the Venice Commission, ${ }^{58}$ are intrinsically linked with what Jeremy Waldron has referred to as the 'original habitat of the [RoL] viz. its role in constraining governments within a national system'.${ }^{59}$ Indeed, the Venice Commission's initial RoL checklist, as well as the complementary benchmarks it developed some years later ${ }^{60}$ are meant 'for evaluating the state of the rule of law in single states' ${ }^{61}$

In the same vein, the 2012 UN 'Declaration of the High-level Meeting of the General Assembly on the Rule of Law at the National and International Levels' ${ }^{62}$ already hints in its title that the RoL is mainly perceived as operating within two State-centric contexts: the 'national' and 'international' levels. According to the Declaration, the RoL is 'the basis on which just and fair societies are built'. The 'global view' as to how the RoL should operate within national systems $\mathrm{s}^{63}$ is a largely 'thick' one, incorporating not only many elements of legality, but also the condition of consistency with 'international human rights norms and standards'. ${ }^{64}$ The RoL is also 'the foundation of friendly and equitable relations between States' ${ }^{65}$ With respect to the international dimension, the Declaration further confirms the UN's commitment

57 Venice Commission, 'Report on the Rule of Law' (n 9) para 16.

58 Ibid paras 41 et seq.

59 Jeremy Waldron, 'Are Sovereigns Entitled to the Benefits of the International Rule of Law?' (2011) 22(2) European Journal of International Law 315, 317.

${ }^{60} \mathrm{CoE}$ Venice Commission, 'Rule of Law Checklist' (18 March 2016) CDL-AD(2016)007.

${ }^{61}$ Venice Commission, 'Report on the Rule of Law' (n 9) 'Annex: Checklist for evaluating the state of the rule of law in single states'.

62 UN General Assembly, 'Declaration of the High-level Meeting of the General Assembly on the Rule of Law at the National and International Levels' (30 November 2012) UN Doc A/Res/67/1.

63 McCorquodale (n 53) 286.

64 UN Security Council, 'The Rule of Law and Transitional Justice in Conflict and Post-conflict Societies: Report of the Secretary-General' (23 August 2004) UN Doc $\mathrm{S} / 2004 / 616$, para 6 . This understanding is also the one reflected on the UN's dedicated webpage, https://www.un.org/ruleoflaw/what-is-the-rule-of-law/.

${ }_{65}$ UNGA, 'Declaration of the High-level Meeting of the General Assembly on the Rule of Law at the National and International Levels' (n 62) Preamble. 
to 'an international order based on the rule of law', ${ }^{66}$ acknowledging that the (I)RoL 'applies to all States equally, and to international organizations, including the United Nations and its principal organs' ${ }^{67}$ A 2013 report of the UN Secretary-General further specifies that, at 'the international level, the rule of law accords predictability and legitimacy to the actions of States, strengthens their sovereign equality and underpins the responsibility of a State to all individuals within its territory and subject to its jurisdiction' ${ }^{68}$ Central to the IRoL ideal is also the "full implementation of the obligations set forth in the Charter of the United Nations and in other international instruments, including the international human rights framework' ${ }^{69}$

Since the international legal order is largely based on States as its creators, its subjects and the primary bearers of international rights and obligations, a strong RoL at both the national and the international levels will therefore imply an effective State, in full command of its capacities in both internal and external affairs. However, the decoupling of governance and State in ALS and the corresponding exercise of functions normally associated with the State by alternative governors will arguably severely undermine the RoL and IRoL ideals. At the domestic level, the main challenges are posed by 'the persistence of legal pluralism in the absence of a collision regime' ${ }^{70}$ More precisely, this refers to the plurality of actors claiming a right to govern (i.e. the central authorities and local/or external alternative governors) and the analogous plurality of overlapping norms and, potentially, State and non-state (justice) institutions 'in the absence of a singular authority that would be able to impose a unitary order'. ${ }^{71}$ Arguably then, the exclusive focus on the nation State and its institutions in the mainstream legal and political discourse is inadequate to address and bring about the conditions necessary for the RoL in ALS. As frequently probed in this volume, the same will be true in respect of the IRoL. Indeed, limited statehood often frustrates a State's ability to fulfil its international obligations, whereas the State-centrism of the international legal system signifies that alternative governors performing functions traditionally related to the State will evade international responsibility for wrongful acts or omissions, thus severely undermining the ideal of a RoL-based international order.

\footnotetext{
66 Ibid para 1.

67 Ibid para 2.

68 UNGA, 'Strengthening and Coordinating United Nations Rule of Law Activities:

Report of the Secretary-General' (29 July 2013) UN Doc A/68/213, para 4.

69 Ibid.

70 Tobias Berger and Milli Lake, 'Human Rights, the Rule of Law and Democracy' in Risse, Börzel and Draude (n 15) 424.

71 Ibid 424-425.
} 
At the very end of its 2011 seminal report on the RoL, under the heading of 'New challenges', the Venice Commission acknowledged that '[a] challenge for the future is how the achievements of the rule of law can be preserved and further developed under circumstances where individuals are increasingly influenced by and linked to new modes of governance' ${ }^{72}$ It then argued that the RoL 'must be tailored in a way that freedom for all will be insured even in areas where hybrid (state-private) actors or private entities are responsible for tasks, which formerly have been the domain of state authorities'. ${ }^{73}$ Finally, the Venice Commission further prompted that the substance of the RoL 'as a guiding principle for the future has to be extended ... to activities of private actors whose power to infringe individual rights has a weight comparable to state power', concluding that '[g]overnmental actors at the national, transnational and international level all have to act as guarantors of the fundamental principles and elements of the traditional rule of law in these areas' ${ }^{74}$ It is with these challenges - which, as already outlined, are neither new nor rare - that this volume is mainly concerned with.

\subsection{THE VOLUME: OBJECT, PURPOSE AND STRUCTURE}

The object and purpose of this volume are to examine and understand the implications of limited statehood and alternative modes of governance for the traditional State-based understanding of the RoL and the equally State-centric framing of the international legal order and the IRoL ideal. As clarified at the outset, the volume builds on previous conceptual research on the ALS phenomenon. Therefore, it will not engage in (too many) theoretical musings on the margins of the concept's underpinnings. Instead, the various contributions to this volume employ the ALS concept as a framework against which they examine some of the questions emerging from the intersection between limited statehood, the RoL and the IRoL. The approach of the volume, however, is not as multidisciplinary as the prior research conducted in the context of the SFB 700. Indeed, while some chapters bring a political science approach, either alone or in combination with a legal approach, the majority of authors contributing to this volume come from the legal discipline and specialize, both within and outside the context of this book, in international law. ALS, as a concept, has rarely been used in international legal discourse. However, as Krieger highlights, limited statehood is a very real 'empirical phenomenon' that has

\footnotetext{
Venice Commission, 'Report on the Rule of Law' (n 9) 66.

Ibid.

Ibid.
} 
a discernible impact on international law. ${ }^{75}$ Since this effect has seldom been examined, this volume also aims to fill a gap in the ALS-related research undertaken thus far by adding a new, mainly international law-oriented perspective.

In view of the above, it should also be clearly stated that this volume is not meant as an exhaustive exploration of the many potential junctions between ALS, alternative governors, and the RoL and IRoL. Rather, the volume studies the following three overarching dimensions or themes meant to broadly answer the following research questions:

1. What specific (I)RoL challenges emerge under conditions of uncertain or contested sovereignty in ALS? How does the alternative governance of outside States or separatist regimes undermine the possibility of a RoL-based international legal order and, in this sense, how can and/or should the international community respond?

2. Just how much can rebels govern, and can their governance be RoL compliant? What happens when rebels and other non-state rulers commit abuses in their exercise of State-like governance functions? Will the State wherein they operate be held responsible under international law, or will they? And, more importantly, how can and/or should these actors be held responsible?

3. How do ALS and violent alternative governors challenge international peace and security? Does the provision of law and order by external, generally stability-providing actors such as the UN conform with the (I)RoL? Can the UN engage in ALS-related counter-terrorism while also upholding and promoting the RoL? And finally, how does the concept of ALS inform the manner in which atrocity prevention and response mechanisms are understood and implemented?

The contributions to this volume will correspondingly be divided into three parts, each comprising three chapters. However, before turning to the more case-specific chapters of the volume, Part I features, alongside this introductory chapter, a theoretical and mainly political science-informed reflection of the RoL-statehood nexus. In Chapter 2, Amichai Magen and Zachariah Parcels consider this nexus in two dialectical sections. First, they highlight the varied and enduring link between the concepts of the State and RoL in modern political and legal thought. Importantly, their contribution also incorporates an empirical analysis that illustrates the strong correlation between the two concepts. Their analysis demonstrates that, as fragility increases, RoL indicators decline, whereas stronger government effectiveness is followed by improve-

75 See, generally, Krieger (n 16). 
ments in RoL indicators. Second, Magen and Parcels offer a contrarian perspective in that they focus on a conceptual shift from institutional features to standards and private ordering in alternative, mainly non-state modes of governance. To this end, the two authors explore various contexts and means in which the State-RoL relationship can be decoupled, as well as some of the obvious limits to this unbundling. Against the contextualizing backdrop of Part I, the second part of the book then moves to explore some of the (I)RoL dilemmas arising from contested sovereignty in ALS. Thereafter, Part III looks at some of the whys and hows of rebel governance in ALS and inquires into forms of responsibility as a response to their potential transgressions under international law. Finally, the fourth and last part of the volume explores some of the ways in which ALS challenge and inform the maintenance of international peace and security.

\subsubsection{Contested Sovereignty in Areas of Limited Statehood and the (International) Rule of Law}

The second part of this volume is mainly concerned with situations in which the governance functions of the legitimate sovereign are either forcibly displaced and/or made impossible by local or external actors that contest the former's sovereign entitlement in a specific ALS. These alternative governors will often be either separatists aspiring to statehood, or outside States acting as (covert) occupiers. Part II starts with our very own chapter (Chapter 3), which centres on the de facto regime, a powerful non-state ruler that also exhibits State-like characteristics. However, in view of its indeterminate legal status, this alternative governor generally resides at the outer limits of the international system, thus profoundly challenging the international legal order. Notably, as our chapter unveils, governance provision by de facto regimes generates a black hole in a State-centric international human rights system. By adopting a thick understanding of the IRoL, our contribution contends that this state of affairs severely undermines the potential of a RoL-based legal order. Finally, Chapter 3 argues that, in light of the extensive power they wield over territory and population, de facto regimes should be brought under the scope of IHRL. This, we believe, would bring us closer to achieving the IRoL ideal.

The far-reaching impact of contested sovereignty on IHRL, but also IHL, is further exposed in Olga Burlyuk's chapter (Chapter 4), which tracks the unravelling of the RoL in Crimea after the occupation and subsequent annexation by Russia, events that also shook the foundations of the IRoL, understood by Burlyuk as the ideal of 'a world governed by rules and not force'. In her chapter, she conceptualizes post-annexation Crimea as not only an ALS, but also an area of contested sovereignty, where Ukraine's statehood is not so much limited as it is absent, being replaced with that of an outside State 
(Russia) as an alternative governor. Burlyuk then examines the RoL dilemmas that the situation in Crimea poses at both the international and domestic levels. Her analysis aptly reveals that, by occupying and annexing Crimea, Russia has upset the international legal order, violating its bilateral and multilateral commitments to Ukraine, the latter's domestic legislation and even its own national norms. Following an overarching analysis, spanning both IHL and IHRL dimensions, Chapter 4 concludes that, under conditions of contested sovereignty, even basic RoL and IRoL thresholds are tenuous. This, Burlyuk argues, is mainly caused by the existence and application of two legal regimes to a territory: one de jure (Ukraine) and one de facto (Russia).

When a claim to sovereignty is contested, it will also have an impact on the legitimacy of the purported sovereign at both the local and the international plane. A lack of legitimacy, as Yaël Ronen argues in Chapter 5 of this volume, will hamper that purported sovereign's ability to govern in a RoL-compliant manner. The example of Israel's (attempted) rule over East Jerusalem, as employed by Ronen, reflects this impasse. Although Israel's claim to sovereignty is rejected by the international community, Ronen does not focus on the question of the territory's international status. Instead, she turns the expected IRoL analysis around, examining the impact of this situation on the domestic RoL from Israel's perspective. To illustrate the various challenges, Ronen narrows her analysis to a single policy area, where local resistance to Israeli administration has arguably been the strongest: the education system. The author examines Israel's three main strategies in response to resistance by the local Palestinian population: enforcement of the law, including through force; adaptation of the law; and turning a blind eye to violations of the law. Ronen concludes that, while these strategies have, at times, succeeded in concealing the gap between the purported sovereign's intended policies and the realities on the ground, they cannot fully mend the impairment of the RoL because they themselves compromise it.

\subsubsection{Rebel Governance in Areas of Limited Statehood and International Responsibility}

The third part of this volume focuses primarily on the alternative governance provided by NSAGs and its consequences for the international legal order. As explained by Benedetta Berti in Chapter 6, NSAGs are groups that are entirely or partly independent of State government and which, to achieve their economic, political or ideological goals threaten to and/or use force. While these groups may vary widely in terms of nature (e.g. criminal organizations, militias, insurgents or terrorists), organizational structure and capacities, the three chapters in Part III focus on those types of groups that establish effective 
control over a part of a State's territory to the exclusion of the latter's authority, creating an ALS where they act as governance providers.

The first chapter in this instalment gives a political science perspective on RoL and law enforcement by NSAGs (Chapter 6). Berti first examines the different logics behind these groups' incentive to establish so-called justice systems in areas under their control. According to Berti, these are mainly based on considerations of expediency, legitimacy and control. She further examines the different configurations of what she names 'rebel justice', looking at the distinct institutions, procedures and functions established by NSAGs. The author also stresses the relational aspect of justice-provision and explores the ways in which rebel groups may rely on the provision of law and order to renegotiate their social position in the existing socio-political order. Berti's analysis concludes that NSAG-established justice systems may meet certain basic RoL requirements. However, she also admits that the association of rebel justice and RoL-based governance creates many tensions, the difficulty of ensuring external monitoring and supervision of NSAGs justice and security provision being chief among them.

Berti's chapter also serves as an excellent precursor to the following two contributions of Part III in that it uncovers that NSAGs provide governance, including law enforcement and justice, more often and more extensively than the international legal system is prepared to deal with. Indeed, in Chapter 7 of this volume, Tatyana Eatwell picks up on this discussion and observes that NSAGs may fill a governance vacuum in ALS and establish their own administration, providing law and order, as well as other essential services. According to Eatwell, most often, NSAGs engage in governance activities in order to support their claim to legitimate authority over the population under their control. In this sense, she further notes that, just as any State-governing authority - or perhaps even more so - 'rebel governors', as she calls them, may abuse the rights and freedoms of those they govern. Her chapter considers the question of responsibility for potential abusive conduct within the traditional State responsibility framework under international law and the principle that a State will normally be held responsible for the conduct of 'agents of necessity'. However, following an extensive analysis of the applicable legal framework, Eatwell concludes that a State may only be held responsible for the wrongful acts or omissions of NSAGs when it gives its consent or acquiesces thereto. Since this is rarely the case, an international responsibility gap therefore emerges. This is where Nicholas Tsagourias steps in with Chapter 8.

In Chapter 8 Tsagourias turns to the question of the international responsibility of what he terms 'non-state rulers', namely actors that exercise effective control over territory and people in ALS. This category may very well include some NSAGs, but also alternative governors acting outside the armed conflict paradigm, such as the de facto regimes discussed in Chapter 3. Tsagourias 
begins his analysis by underlining the challenges that limited statehood and the emergence of non-state rulers pose to international law and, more specifically, to the institution of international responsibility as a crucial instrument in the implementation and enforcement of international law and the IRoL. To close the responsibility vacuum in ALS, the author puts forward a normative framework meant to hold non-state rulers directly responsible for breaches of international law. The framework proposed by Tsagourias is de lege ferenda and draws on analogies from general international law and the law on State responsibility. Therefore, the author also discusses the conditions under which non-state rulers could be considered subjects of international law, and the requirements under which wrongful conduct may be attributed to them, engaging their responsibility. However, as Tsagourias concludes, such a normative framework would require a complete overhaul of the international legal system, a very challenging endeavour considering the system's still prevalent State-centrism.

\subsubsection{Areas of Limited Statehood and the Maintenance of International Peace and Security}

In a number of cases ALS have proven to be a breeding ground not only for ordinary crimes, but also terrorism or even grave crimes such as genocide, war crimes, ethnic cleansing or crimes against humanity. When they occur, events such as these will often threaten international peace and security and elicit responses from other States and international actors such as the UN, an organization whose very purpose is 'to maintain international peace and security' ${ }^{76}$ International reactions are generally prompted by human rights and RoL and IRoL concerns. However, the involvement of external actors may also raise similar concerns. It is with such issues that the fourth and last part of this volume is concerned.

Pia Hesse starts this conversation by exploring the question of extraterritorial law enforcement in ALS (Chapter 9). To this end, she focuses mainly on measures carried out in the context of UN peacekeeping missions. She describes how ALS are plagued by severe governance gaps, in particular in the realm of security, which may provoke external agents to assume operational control of local policing. When this happens in the context of UN-authorized peacekeeping missions, at least three legal orders will generally compete to be applied: international law; the domestic law of the State hosting the mission; and the domestic law of the intervening State(s). Hesse argues that, while the legal grounds on which enforcement measures are based often remain

76 UN Charter (n 24) art 1(1). 
unclear, basic RoL principles such as legality or legal certainty should apply to extraterritorial policing. Following an examination of both domestic and international law norms in the context of various UN peacekeeping missions, she concludes that most forms of cross-border policing lag behind in terms of a legal framework that would render this practice in conformity with the RoL at both the domestic and the international level. This, Hesse contends, is the result of a State-centric and sovereignty-oriented order that does not provide for scenarios where external actors, prompted by the inability of a State, take up the exercise of public powers in respect of that State's population.

When armed conflicts between government forces and UN-designated terrorist groups such as the Islamic State of Iraq and Levant or Boko Haram occur in ALS, the RoL is severely threatened therein. In Chapter 10 of this book Jessica Almqvist critically examines UN responses to this phenomenon. A basic problem of the current framework, she notes, is that the design of the international counter-terrorism regime is limited in its ability to improve RoL conditions in ALS ruled by international terrorists. As Almqvist underscores in her extensive analysis, the UN's approach is mainly centred on coercive measures - including the use of force by outside States - to compel these groups to relinquish their control over ALS. At the same time, impunity for grave crimes and serious human rights violations perpetrated in these contexts remains widespread. Almqvist further raises the alarm that this approach is deeply problematic and counterproductive to the goal of eliminating international terrorism. To this end, the author makes the argument that the current strategy must be replaced with one that prioritizes RoL restoration, including through the impartial investigation and prosecution of grave crimes committed by all actors involved in these conflicts, be they international, regional or national ones.

In Chapter 11, which is also the last contribution to Part IV and this volume, Kenneth Chan reflects on the impact of the unique features of the ALS phenomenon on issues of prediction, early warning and prevention of atrocities in the context of the R2P doctrine. More specifically, this chapter inquires whether the fragmentation of statehood itself is a risk factor, or whether non-state governors can mitigate perceived risks through their assumption of governance over ALS. While Chan concedes that limited statehood does not lend itself to easy analysis, particularly in the context of the atrocity prevention frameworks associated with the R2P doctrine, he also argues that such a state of affairs must be substantiated through scrutiny of the specific circumstances leading to the interruption of sovereignty, and the conditions emerging from this change in the territorial status quo. In this respect, the chapter highlights a number of relevant factors and observations to illustrate potential synergies between the ALS framework and the R2P doctrine. In so doing, the author 
means to further our understanding of the underlying challenges relating to atrocity prevention in ALS.

After exposing and examining some of the main political and legal dilemmas arising at the junction between ALS, alternative governors and the (I)RoL, no truly clear-cut answers seem to emerge. Rather, as Berti also observes in Chapter 5, future research on ALS and alternative governors should further problematize and decouple the notion of the RoL from the State. Here, we would argue for a corresponding research need in relation to the IRoL, which is also highly intertwined and dependent on the sovereign State and a State-centric international system and thus undermined by the ALS phenomenon. As indicated earlier, the contributions to this volume have given us, first and foremost, a descriptive account of the myriad ways in which ALS and alternative governors challenge the RoL, IRoL and, more widely, the international legal order. However, these chapters also represent an incipient normative interrogation of how international law and the traditional understanding of the RoL-State nexus ought to develop in order to provoke a shift in our focus from examining the question of the RoL and limited statehood, to a more thorough exploration of the RoL in ALS and an international legal order that brings alternative modes of governance under its scope. 